\title{
MY PROFESSIONAL JOURNEY: AN AUTOBIOGRAPHICAL NARRATIVE
}

\author{
Le Van Canh* \\ Faculty of English, VNU University of Languages and International Studies, \\ Pham Van Dong, Cau Giay, Hanoi, Vietnam
}

Received 27 July 2018

Revised 25 September 2018; Accepted 26 September 2018

\begin{abstract}
This paper underscores the dynamic and complex dimensions of my being and becoming an applied linguist. It employs autobiography as an approach to my engagement in self-reflexivity on the professional re-construction of myself. The purpose behind this self-reflective account is to encourage an access to localized ways of knowing, being, and becoming in the world. That access is much needed in language education research in the era in which epistemological understandings are in flux. The paper concludes by discussing how I re-construe my own professional experiences.
\end{abstract}

Keywords: autobiographical narrative, professional journey, professional growth, learning English, teaching English, applied linguistics

\section{Introduction}

I am invited to write an article for the Special Issue of the VNU Journal of Foreign Studies run by the VNU University of Languages and International Studies (ULIS) to mark the $60^{\text {th }}$ anniversary of the university's English Department. I think it could be best to tell the story of my learning and professional trajectory, which is full of twists and turns, for the purpose of exploring, connecting, sharing and learning. As Barkhuizen, Benson, and Chik (2014, p. 37) have asserted, "Language learning histories (LLHs) are retrospective accounts of past learning. They are the written stories of language learning experiences."

* Tel: 84-913563126

Email: canhvanle@vnu.edu.vn /

levancanhvnu@gmail.com
They can be as extensive as all the life span of a person's learning experience or they can be limited to smaller units like school year, semester or classes. In this autobiographical narrative, my case is related to the former, i.e., my life-long learning experiences. As I have spent forty-five years of my life studying and working at ULIS, I hope that my professional story can shed some light on the 60-year-long history of the English Department. The paper begins by contextualizing autobiography as a research method in applied linguistics in general and in second language teacher education in particular. It next presents the professional trajectories I have experienced from an English language learner to an English language teacher, an English language teacher educator, and then an applied linguist. The paper concludes with 
the discussion of how I re-construe my own professional experiences.

\section{Contextualization}

In the field of English language education, there are diverse realities that describe English-language teachers. Each reality comes from a collection of experiences and paths that determine the practice of individual teachers. One of these realities is the one portrayed in the teacher's autobiographical narrative, which is understood as a subjective interpretation of one own's life. In other words, although teachers share their occupation, they are far from sharing life stories. Every teacher may be considered a unique world, with a particular voice portraying their own life stories and experiences. As a result, the use of autobiography as a research method has become increasingly recognized in social sciences and applied linguistics research over the past couple of decades (Barkhuizen, et al., 2014; Pavlenko, 2007; Coffey, 2014). Coffey (2014, p. 1) describes autobiography as "the telling and documenting of one's own life". According to Pavlenko (2007, p. 164-165), "autobiographic narratives offer three major contributions to research on SLA [Second Language Acquisition] and bilingualism. First of all, they offer insights into people's private worlds, inaccessible to experimental methodologies, and thus provide the insider's view of the processes of language learning, attrition, and use. Secondly, they highlight new connections between various learning processes and phenomena, and, in doing so, point to new directions for future research. Thirdly, autobiographic narratives constitute a valuable information source for historic and diachronic sociolinguistic research in contexts where other sources are scarce (Nekvapil, 2003)." In a similar vein, Barkhuizen, et al. (2014) note, "selfnarratives, or the stories people tell about themselves, help us to understand the ways in which individuals situate themselves and their activities in the world." (p. 2). In the field of teacher education research, the interest in autobiographical narratives is grounded in the belief that "in telling their stories of experience teachers necessarily reflect on those experiences and thus make meaning of them; that is, they gain an understanding of their teaching knowledge and practice" (Barkhuizen \& Wette, 2008, p. 374). Ellis (1997) argues that "teachers of second and foreign languages, it might be argued, do not exist as a collective, but are highly differentiated in terms of their background knowledge, their personal goals, who they teach and the conditions under which they teach" (p. 246). Therefore, knowing that we are preparing ourselves to become English language teachers, we must understand how our personal histories may impact our jobs.

Accordingly, autographical narratives have become a source of inspiration to many scholars and researchers in the field of second language teacher education and applied linguistics. Borg (2013) encourages the use of autobiographical narratives to explore teachers' own experiences in classrooms and schools. Casanave and Schecter's (1997) book, for example, is a collection of stories and reflections written by language educators from diverse backgrounds and working contexts. Each contribution is a personal narrative, and the book overall presents a study of personal issues in language education. Canagarajah (2012) presents his story of professionalization as a periphery professional in TESOL through means of an analytic autoethnography (Anderson, 2006). Canagarajah explains that in an autobiographical approach, 
writing functions not only as a means of disseminating knowledge and experience, it is a central activity for generating, recording, and analyzing data. In writing his narrative he engages explicitly with the situatedness of his experiences, acknowledging that "knowledge is based on one's location and identities" (2012, p. 260) and that "narratives represent knowledge from the bottom up ... [which is] open to further interpretation" (Canagarajah, 1996, p. 327, original emphasis). In sum, an autographical narrative is a communicative space where the writer-teacher takes up personal issues of being, becoming, and belonging in contextual and relational analyses of their situated experiences.

The purpose behind this autographical narrative is to self-reflect on how the role of my background, my knowledge and the conditions in which I have been working has historically and diachronically played in my professional life. It entails processes through which I have reflected on and reconstructed my own professional life and professional identity. Throughout the process of writing my own narrative, I was often reminded of the shifting sands of time and space. Thus, my own biographical account can be a source of reference to other English-languageteaching (ELT) professionals and applied linguists working from both inside Vietnam and outside Vietnam for insightful analysis of how I exercises agency and shape myself as an ELT teacher, teacher educator and applied linguist.

Reflecting on my experiences as a language learner, language teacher, and an applied linguist through my autographical narrative I have managed to identify valuable strengths from my lived experiences, which have helped me to gain better understandings of who I am as an applied linguist and of my professional landscape.

\section{Becoming an English language learner}

In November 1974, I, at the age of 19, was admitted into the Hanoi College of Foreign Language Teachers (now VNU University of Languages and International Studies) through the national entrance examination. Neither the College nor English was my choice. It was arranged by unknown people. Born and raised in a poverty-stricken rural area, I thought the College had a beautiful campus with highrise buildings. Having set foot on the campus, I was shocked seeing a few long thatchroofed houses with walls being made of clay surrounded by green paddy fields. Soon, I realized that those cottage houses were the faculty residence and student dormitories. In addition, there were a couple of brick twoand four-storey buildings, the former seating the College's Administration and the library while the latter housing the classrooms.

At that time, Russian and Chinese were two dominant foreign languages taught at secondary and tertiary levels of education. English was considered to be the language spoken in capitalist countries and as a result it did not have any social status. While I was arranged to take the teacher training programme, very few upper secondary schools taught English. Consequently, I had quite a vague idea of my future career though this fact did not bother me much (probably because of then societal milieu). I also realized that the College English language lecturers were equally low in the social and economic ladder as compared with their Russian or French language peers.

It was the first time in my life I had learned English and I found English so difficult to learn, particularly its pronunciation. During the first semester of the first year at the College, every time the teacher asked me to read aloud English words, most of the 
classmates laughed at me because of my 'funny' pronunciation. The English sounds seemed to be too challenging to me. Honestly speaking, I was so frustrated with my learning that I from time to time thought of quitting. However, all the lecturers from the English Department were so helpful and enthusiastic. Besides the classroom hours, they, in the evening, visited the students frequently at the thatched dormitory lit by kerosene lamps, providing tutorials to the students. What impressed me was that everybody worked so hard both individually and in groups albeit without clearly-defined reasons of learning English. And everybody was making progress to varying degrees, which was reflected in their progress test scores. This encouraged me a great deal and I talked to myself that if I worked harder, I could learn better. I practiced the English pronunciation day and night, reading aloud single sounds or words repeatedly. My throat became hoarse. I got up as early as possible every morning, lying in bed and practicing English sounds. Despite my great effort, progress was invisible. I felt so shy and humiliated every time I was called to read English in the classroom. It was not until the beginning of the second year of the training programme when improvement in my English pronunciation was surfaced. Having completed the second year of the training programme, I began to find myself feeling tremendous affection toward English, and I had a completely different sense of myself as a language learner. This motivated me to work harder and move to the ever higher level of academic performance as reflected in the better marks I was given in the forms-focused progress and achievement tests.

Like all other students of my time, I was taught English with a Grammar-Translation Method. During the first two years, the 'textbook' were written by Vietnamese authors, all being the College's senior lecturers. Each lesson was composed of pronunciation drill exercises, a text and formsfocused exercises. For the last three years of the training program, the textbooks used were all written by Soviet linguists with a focus on classic English literature and forms-focused exercises. While being called 'textbooks', they were actually stenciled copies of the original version with pages of each individual lesson pinned together and distributed to the students on the weekly basis. More often than not, students did not have the 'textbook' until the lesson had been taught. There was no such a thing as skill-based teaching and nobody had ever known of Communicative Language Teaching. A dictionary was a dreamed luxury not only to students but to the majority of lecturers as well. Actually, the first bilingual English-Vietnamese dictionary was not available on bookshop shelves in Northern Vietnam until 1980.

The grammar-and-literature biased pedagogy did little to encourage oral and written discourse in English. Listen-andrepeat and reading aloud were two main classroom activities. My classmates and I listened and repeated sounds and words after the teacher because there was not any taperecorder at that time. In terms of speaking, we never went beyond a short single sentence as the teachers tended to ask each individual student to make up their own sentence with a particular grammatical structure or a word or a lexical phrase. Regarding writing, we were often asked to write either dictations or an essay but the primary focus in writing was on grammaticality. The academic style of writing and citation styles were never taught. Unsurprisingly, I did not know anything about topic sentences, supporting sentences, coherence or cohesion. If our writing was grammatically correct, we got good marks. My 
writing skills in Vietnamese were so helpful to me in writing English 'essays' because I was one of the best students at Vietnamese literature at secondary school. This explained the great difficulty I had in writing the course assignment following my admission to the Master's Degree programme in TESOL in 1996. While my lexical and grammatical knowledge was not so bad, my ability to speak and to understand spoken English was limited. This is because I, like all other students, had to learn and memorize a large vocabulary size and abstract grammatical rules for examinations.

When I became the fourth-year student, I was, for the first time, taught a subject called Teaching Methods. The text was entitled " $A$ Conscious-Practical Approach to Foreign Language Teaching", written by G. V. Rogova, who was on the faculty of Moscow State University. The author divided her manual of 17 chapters into three parts covering (i) aims, content and principles of foreign language teaching; (ii) approaches to the teaching of various language skills including translation; and (iii) curriculum and structure of the school system. The book was underpinned by the assumed homogeneity in classroom materials and methods, as might be expected from the centralized political system.

Unquestionably, both my peers and myself had trouble learning English as a major due to inadequate resources or pedagogy. However, everybody was engaged in learning the target language. It was our desire to become effective users of the target language that explained why we performed well academically despite limited quality learning opportunities.

\section{Becoming an ELT teacher}

Although being an EFL teacher was not what I really wanted, I at last made it professionally. I became a full-time EFL teacher at the English Department in October 1979 and worked there until 1998 when I was assigned to take an administrative position in the College. The reason for being staffed at the English Department was my high scores in the graduation form-centred examinations rather than my pedagogical competence. I did not like the teaching position at the Department at all but I had no choice because it was almost impossible to be given a job as an English language teacher in high schools at that time. Many of my classmates who were sent to high schools in the remote rural or mountainous areas were assigned to teach physical education or to run errant in the school because nobody was learning English. The centrally-planned economy did not care about actual labour needs.

During my first years of teaching, I had no idea of the nuts and bolts of teaching English, and I taught my students the way I had been taught by my teachers at the College. To use the modern jargon, my teaching was shaped by 'the apprenticeship of observation' (Lortie, 1975). It was kind of "intuitive and imitative" or "folkways of teaching" (Lortie, 1975). Luckily, by the time I became an EFL teachers, the Communicative Approach to English language teaching had been introduced into Vietnam via teachers who had been offered scholarship by the Australian Government to study TESOL in Australian universities. These western-trained lecturers were assigned with a dual role as both professional group leaders and mentors within the Department. While everybody was talking about the Communicative Approach, not many members of the Department knew what it was exactly like. In addition, the limited resources did not allow anyone to use it even though they were knowledgeable about it. Put it bluntly, the Communicative Approach was largely rhetorical. My classroom teaching 
remained to be 'hit and miss' and based upon a lot of instincts. Some were good instincts; others were not. Honestly, I did not realize that I felt into the trap of teaching like I had been taught. I know now that I should not have taught like this; I should not have been this kind of teacher, but at that time I did not have any other experiences and knowledge to do otherwise. Although I was not sure whether my students learned anything from my teaching, I certainly underwent a steep learning curve over the course of the first few years of teaching. I learned how to plan a lesson, how to explain the complicated and abstract grammar rules in a more accessible manner to my students. Particularly, I learned of the importance of good rapport in motivating the students.

Within the College and nation-wide, scholarship and intellectual advancement were almost at a standstill. No seminars and workshops were available while the library had few English-language titles donated by the Soviet Union. Every week, besides teaching, teachers in the Department had one group meeting during which the group leaders and mentors, who returned from their MA TESOL programme in Australia, guided everybody to discuss how to teach the adapted version of the western commercial textbooks like the Kernel Lesson series (Neill, 1971), or Mainline English series (Watson \& Quinn, 1975), which were brought home from overseas by group leaders and mentors themselves, who also did the adaptation. It was kind of Lesson Study though nobody knew of this term then. I managed to learn a lot professionally from this experience. Through these activities I realized that each teacher had her or his own styles, which were totally different from each other. This had a great impact on my own teaching practice and professional awareness.
In December 1995, I got a scholarship to take a three-month course on language teaching and test-item writing at the then University of Cambridge Local Examination Syndicate (now Cambridge ESOL) in the UK. As the product of the Grammar-Translation Method, I found myself unable to speak English intelligibly and to understand spoken English in Cambridge. I asked one of my professors for help and she advised me to go to the University Library to borrow tapes and a tape-recorder and practise listening and improving pronunciation simultaneously. I followed her advice, working intensively after the class hours. During the weekend, I visited different interesting places there, taking advantage of every opportunity I was offered to practice conversing with the people I happened to come across with. After a month, I, to my excitement, made good progress, which impressed my professors positively. In addition to pronunciation, listening and speaking, I managed to read some basic books about English teaching methodology to complete my home assignments. The two books that were so helpful to me were Widdowson's (1990) Aspects of Language Teaching and LarsenFreeman's (1986) Techniques and Principles in Language Teaching. I found the latter more useful because the book not only introduced different teaching techniques but the principles underlying each technique as well. Although this was a short, intensive course, I benefited much from the way professors provided us with hands-on experience in writing and validating test items as well as interpreting test scores and the fundamentals of English language teaching. I left Cambridge (UK) with some professional expertise and somehow the Cambridge accent.

In July 1996, I was fortunate to be offered a scholarship to complete my graduate training in TESOL for the Master Degree at Saint Michael's College, which 
is located in Vermont of the United States of America. It was the first time I had had the opportunity to study the theoretical and practical aspects of TESOL systematically. I was particularly interested in the Second Language Acquisition Theories Course, especially Vygotsky's sociocultural theory and its implications for language teaching. As I was fully aware that this might be my once-in-a-lifetime opportunity to develop my professional competence, I made full use of the library and the classroom discussions to expand my professional vision. The trouble was I did not know the difference between reading academic texts and reading fiction, so I had to struggle with the required readings of the professional literature. Luckily the courses on Academic writing helped me to develop my scholarly writing and reading skills. The beauty of the Master's Degree Course at Saint Michael's was that we had to complete it within three summers instead of full-year attendance. This gave me ample opportunities to experiment different things I learnt from the course in my real classrooms. Also, it was this activity that brought me to Action Research as a tool for my professional growth. Through that independent study process, I realized the limitations of the western-initiated notions of Communicative Approach and Communicative Competence when applied to my Vietnamese context. Regretably, I was not confident enough to publish these empirical findings. However, I managed to publish it latter under the title "Language Pedagogy and Vietnamese Contexts". I gradually came to be aware of the need to localize teaching, and this awareness has always accompanied me on my professional journey both as a teacher, teacher educator and researcher. After three summers, I became more confident in teaching with a Master's degree in TESOL under my belt.

\section{From an ELT teacher to an applied linguist}

In December 1999, immediately after I had completed my graduate study and returned to Vietnam, I was invited to be a plenary speaker together with Professor Alastair Pennycook, Professor James W. Tollefson, and Professor Diana Larsen-Freeman at the first-ever international conference on ELT in Vietnam co-organized by the Asian Institute of Technology (AIT) in Thailand and the Center for British Teachers (CfBT) in Hanoi. I was reluctant to accept the invitation because I had no experience attending a big international professional conference and I had no idea what was expected of a plenary speaker. However, with the organizer's encouragement, I managed to use the knowledge I had gained from the Saint Michael's graduate course as well as my understanding of the need to contextualize western-based theoretical knowledge, particularly the empirical evidence of the limitations of the Communicative Approach to language teaching as mentioned earlier. My presentation left a good impression on the conference participants and the organizers. This initial success ignited a spark on my imagined horizon. My first attempt at publication came in the wake of the conference, placing the first milestone on my academic journey.

Unfortunately, the administrative work took up much of my time, wisdom and energy. While I managed to spend little time keeping abreast of the on-going developments in the field by reading the internet resources, I was unable to do scholarly work wholeheartedly. As my passion for professional development remained intact, I took time to do independent reading of journal articles that I could 
access, and carried out investigations into my own classes with the graduate students. I developed a better understanding of the methodological issues, the learners, the politics of ELT, and the situated challenges in teaching and learning English in diverse contexts within Vietnam. From time to time, during the summer holiday, when I was involved in in-service teacher training, I chatted with the teacher participants to find out about their beliefs about teaching as well as their working conditions. The information I gained helped me to uncover one important fact that formal training was of little help to teachers' instructional practice, which was largely driven by their mental lives.

I then decided to do my doctoral study with the University of Waikato in New Zealand at the age of 53. Having examined my research proposal, the academic committee allowed me to choose either full or partial campus residency to complete my study. I preferred the latter option to cut down on the expenses, but this means that I had to wear two hats simultaneously: as a full-time administrator at my university and as a 'full-time' doctoral student at the University of Waikato. During this period (2007-2011), I had a couple of times thought of quitting because of physical exhaustion. I was like a battery, becoming empty while in Vietnam, but being fully recharged everytime I was back to the University of Waikato, working with my supervisors. I became self-determined again to get myself back on track. Honestly, what prompted me to go on and complete my doctoral journey was the deep sense of moral obligation to complete what I had been obliged to do in return for the moral and material support from my wife, my children and my supervisors. Finally, the day when I had the viva came and it was a success.
During the process of completing my thesis on teachers' beliefs I found that unlike most of the studies on the same topic conducted elsewhere, there was no divergence between teachers' beliefs and their actual practice. By analyzing the interview and stimulated recall data, I realized that most high school EFL teachers in Vietnam did not have access to the global community discourses, and their teaching was therefore determined completely by their distributed cognition shaped by their unquestioned experience working in a highly centralized educational system within which teachers did not have the power to exercise their agency.

In 2015, I retired from the administrative work to concentrate on my academic activities. Ever since I have been my own boss, enjoying the full freedom to pursue my professional interest. I am engaged in teaching, doing research and publishing my research on international journals, examining overseas doctoral dissertations and giving presentations at international professional conferences. I also work as a reviewer and a commissioned book reviewer for some top international journals in TESOL and applied linguistics. It takes up some of my time, but I find it beneficial professionally. On the one hand, I understand that an invitation to work as a reviewer for internationally prestigious journals is a recognition of my expertise. On the other hand, I can learn much not only from the submitted manuscripts or published books but also from the comments by other reviewers. All these valuable opportunities stimulate me to rethink of my personal professionalism. I have a better sense of who I am as a teacher, teacher trainer and researcher. In effect, those experiences are really enlightening to me as they raise my awareness of the complexity of language learning and teacher learning as well as that of doing research in the absence of a healthy academic and research culture. I share 
Richards's (2012, p. 52) view that "Becoming an English language teachers mean becoming part of a worldwide community of professionals with shared goals, values, discourse, and practices." By engaging in reflective activity and research, I not only continue to develop my knowledge and skills as a language teacher, teacher educator, and researcher, but also come to be aware of who I am in the communities of practice.

I have come to realize that one of the major accounts for the failure of English language education in several contexts is the narrow view of second language learning as just a mental processing activity with a focus on input, interaction, and feedback, thereby viewing learners as asocial beings. This view of learning leads to a reductionist view of teaching according to which teaching is reduced to method. I have learned from my professional experience that effective teaching is not the product of a particular method; rather it is the product of the teacher's imagination and creativity in making the lesson socially constructed. That imagination and creativity are resulted from the teacher's solid knowledge base which is constantly expanded with the teacher's practical experience and sensitivity. This constitutes a great challenge, if not the greatest challenge, to English language teacher education.

\section{Conclusion}

Barkhuizen (2011) uses the term 'narrative knowledging' to refer to a cognitive activity of making sense of and reshaping experience. By narrating my own professional experience, I investigated my own practice in an attempt to understand better that experience, thereby generating knowledge.

Writing this autobiographical narrative provides me with a moment to step back and dig deeper into my feelings and gain understanding of why I was doing things I had done and feeling the way I had felt. It is also an opportunity for me to think of how to encourage professional maturity and nurture personal interests. It is a practice of mindfulness. The analysis of my own autobiographical narrative revitalizes my lived experiences.

My experience in learning English as a foreign language in the input-poor, low-resource and instructed context instances that the trumpet for 'the younger, the better' is mythical and ideological. The claim that it is impossible to become fluent in a foreign language after puberty is nothing more than a terrible misrepresentation of a scientific outcome motivated by neoliberal ideology. I am convinced that it is possible to become an effective user of a foreign language at any age, and small imperfections of grammar or accent often just add to the charm. It is thus immoral to blame failures in foreign language learning on age. Language learning is basically emotion-driven.

For almost 40 years in the teaching career, my attitude to, and passion for teaching English, educating teachers and doing scholarly work have changed positively. Although I liked neither English nor the job of teaching English at first, I have come to love my job and I have no regrets whatsoever. I am better aware of the fact that being a teacher, I am always a learner, and my learners and the teachers I have worked with are my wonderful teachers. I have learned no less from them than from the professional literature. It is the lessons I have learned from them that has taught me what works and what does not work in the diverse Englishlanguage learning contexts within and beyond Vietnam. These practical, contextually-situated lessons, when enlightened with my theoretical knowledge, have helped me to become what I am today as an applied linguist. My research is guided by my praxis that has been shaped by those lessons that language teaching and 
learning and socially constituted and that the goal of research in applied linguistics is not to find consistency, to prove, to disprove, or to predict. Rather, the goals are to interpret, understand and gain insights into specific contexts as exemplified between the researcher and the researched, often in the form of dialogue. In other words, educational research is socially constructed, too.

My greatest professional desire is that one day all Vietnamese ELT professionals will be supported to find themselves working in a healthy academic and research culture towards concerted efforts in opening spaces for English language learning and teaching that are driven by imagination, identity, aesthetics, youth culture, heritage, and other dimensions of life for a revised ecology of English language education specific to Vietnam rather than aping what is promoted in the Anglo-European-American discourses. Gone is the day of grand narratives in applied linguistics. Contextually-situated success stories cannot always be transferable to other contexts. More importantly, what is in vogue may not be the truth.

\section{References}

Anderson, L. (2006). Analytic autoethnography. Journal of Contemporary Ethnography, 35, 373-395.

Barkhuizen, G. (2011). Narrative knowledging in TESOL. TESOL Quarterly, 45(3), 391-414.

Barkhuizen, G., \& Wette, R. (2008). Narrative frames for investigating the experiences of language teachers. System, 36(3) 372-387.
Barkhuizen, G., Benson, P., \& Chik, A. (2014). Narrative inquiry in language teaching and learning research. New York: Taylor \& Francis.

Borg, S. (2013). Teacher research in language teaching. A critical analysis. Cambridge: Cambridge University Press.

Canagarajah, A. S. (1996). From critical research practice to critical research reporting. TESOL Quarterly, 30(2), 321-331.

Canagarajah, A. S. (2012). Teacher development in a global profession: An autoethnography. TESOL Quarterly, 46(2), 258-279.

Casanave, C., \& Schecter, S. (Eds.). (1997). On becoming a language educator. Mahwah, NJ:Lawrence Erlbaum.

Coffey, A. (2004). Autobiography. In M. S. LewisBeck, A. Bryman, \& T. F. Liao (Eds.), The SAGE encyclopedia of social science research methods (pp. 46-47). Thousand Oaks, CA: Sage Publications.

Ellis, R. (1997). SLA research and language teaching. Oxford: Oxford University Press.

Larsen-Freeman, D. (1986). Techniques and principles in language teaching. New York: Oxford University Press.

Lortie, D. (1975). Schoolteacher: A sociological study. London: University of Chicago Press.

Neill, R. O. (1971). Kernel lessons. London: Longman.

Pavlenko, A. (2007). Autobiographic narratives as data in applied linguistics. Applied Linguistics, 28(2), 163-188.

Richards, J. C. (2012). Competence and performance in language teaching. In A. Burns \& J. C. Richards (Eds.), The Cambridge guide to pedagogy and practice in second language teaching (pp. 46-59). New York: Cambridge University Press.

Watson, T.F., \& Quinn, G. H. (1975). Mainline English. Harper Collins Distribution Services.

Widdowson, H.G. (1990). Aspects of language teaching. Oxford: Oxford University Press. 


\title{
HỒI KÝ TỰ THUẬT VỀ CON ĐƯỜNG CHUYÊN MÔN CỦA TÔI
}

\author{
Lê Văn Canh \\ Khoa Tiếng Anh, Truoòng Đại học Ngoại ngũ, ĐHQGHN, \\ Phạm Văn Đồng, Cầu Giáy, Hà Nội, Việt Nam
}

Tóm tắt: Bài báo này nêu bật những khía cạnh biến động và phức hợp trong con đường chuyên môn của tôi từ một giáo viên tiếng Anh trở thành học giả trong lĩnh vực ngôn ngữ học ứng dụng của tôi. Sử dụng phương pháp hồi ký tự thuật, bài báo kể lại quá trình tự phản tỉnh và tái kiến tạo bản ngã. Mục đích của bài tự phản tỉnh này là nhằm khích lệ cách tiếp cận những phương thức thực tiễn về tri kiến, hiện hữu và biến đổi trong đời thực. Phương thức tiếp cận này rất cần thiết trong nghiên cứu giáo dục ngoại ngữ ở thời đại mà những quan điểm về tri thức luận biến đổi không ngừng. Bài báo kết luận bằng những điều phản tỉnh về quá trình cảm thức lại những trải nghiệm trong con đường phát triển chuyên môn của tôi.

Tù khóa: hồi ký tự thuật, con đường chuyên môn, phát triển chuyên môn, học tiếng Anh, giảng dạy tiếng Anh, ngôn ngữ học ứng dụng 